\title{
The Amplification and Application of Ribosomal RNA (rDNA) Gene Sequences of Blidingia minima (Chlorophyta, Blidingia)
}

\author{
Yuan Ao, Weijie Shen, Anxiang Yuan, Yi Yin, Yuan He, Songdong Shen* \\ Department of Cell Biology, School of Biology and Basic Medical Sciences, Soochow University, Suzhou, China \\ Email: *shensongdong@suda.edu.cn
}

How to cite this paper: Ao, Y., Shen, W.J., Yuan, A.X., Yin, Y., He, Y. and Shen, S.D. (2020) The Amplification and Application of Ribosomal RNA (rDNA) Gene Sequences of Blidingia minima (Chlorophyta, Blidingia). Open Journal of Marine Science, 10, 177-190.

https://doi.org/10.4236/ojms.2020.103014

Received: March 1, 2020

Accepted: July 20, 2020

Published: July 23, 2020

Copyright $\odot 2020$ by author(s) and Scientific Research Publishing Inc. This work is licensed under the Creative Commons Attribution International License (CC BY 4.0).

http://creativecommons.org/licenses/by/4.0/

(c) (i) Open Access

\begin{abstract}
The sequence of the ribosomal RNA gene (rDNA) plays an important role in species identification and phylogenetic analysis. However, the only published full-length sequence of a ribosomal gene of green algae is that of Ulva mutabilis. In this study, we amplified the full-length sequence of each ribosomal gene unit of the ribosomal gene of Blidingia minima. The full-length sequence of the ribosomal gene in Blidingia minima is $8676 \mathrm{bp}$, including the $1759 \mathrm{bp} 18 \mathrm{~S}$ rDNA, 576 bp internal transcribed spacer (ITS) $+5.8 \mathrm{~S}$ rDNA, 3282 bp $28 \mathrm{~S}$ rDNA, and 3059 bp intergenic spacer (IGS) region. We then carried out a series of genetic analyses based on the ITS and IGS sequences, to verify whether IGS sequences are useful for studying the genetic diversity of green algae from different locations. We amplified the IGS sequences of Blidingia minima from 10 different locations in the Yellow Sea. Multiple alignments of the IGS sequences of samples from these 10 different sites revealed varying degrees of base differences, and comparative analysis of the ITS sequences revealed that our amplified species was classified as Blidingia minima and distinct from other green algae. In conclusion, our full-length amplified ribosomal gene provides useful information to enrich the data on green algae ribosomal genes and provides an effective molecular marker for the analysis of the interspecies and intraspecies relationships of Blidingia minima.
\end{abstract}

\section{Keywords}

Blidingia minima, rDNA, IGS (Intergenic Spacer), Intraspecies Relationships

\section{Introduction}

From 2007 to 2018, large-scale green tide events occurred every year in the Yellow Sea of China. The event was caused by the excessive deposition of fertilizers 
combined with increased temperatures [1] [2], and such events have a negative impact on the local economy and the environment. In addition, green tides can be dispersed by wind and currents to other coastal areas [3]. The world's largest green tide events were mainly caused by Ulva prolifera O. F. Müller (Chlorophyta, Ulvophyceae), which erupted in 2008 in Qingdao on the Yellow Sea coast in north-eastern China. Based on satellite remote sensing images, it has been postulated that the origin of the green tide was closely related to the expansion of Pyropia aquaculture regions along the coastline of Jiangsu Province [4] [5]. There was molecular evidence that the species attached on the raft in Jiangsu Province and the species that caused the green tide were the same [3]. In addition to $U$. prolifera, a variety of other green algae were also identified on the $P y$ ropia farming raft. Another of the fixed green algae species growing on the $P y$ ropia farming rafts throughout the year is a Blidingia species with extensive biomass (Figure 1). Blidingia has similar habits to U. prolifera on the Pyropia farming rafts. The growth of large quantities of green algae on the Pyropia farming raft, especially Ulva prolifera and Blidingia minima, causes large economic losses to the aquaculture industries in China. During the outbreak of green tide, the biomass of Ulva prolifera is predominant. The biomass of other green algae, such as Ulva flexuosa and Ulva compressa, gradually decreased, but the amount of Blidingia minima remained almost unchanged. Few studies have shown why Blidingia minima can grow on Pyropia farming rafts throughout the year. Therefore, our amplified ribosomal gene cluster can provide some molecular information for subsequent research.

In eukaryotes, nuclear ribosomal DNA (nrDNA) is a cluster structure composed of multiple tandem transcription units, and each rDNA transcriptional unit consists of three rRNA coding sequences (the 18S rDNA gene, 5.8S rDNA gene and 28S rDNA gene), two internal transcribed spacers (ITSs) and one intergenic spacer (IGS) [6] [7] [8]. Due to different evolutionary rates, different regions of ribosomal transcription units can be regarded as molecular markers for species identification and phylogenetic studies at different levels in marine algal research. Reference [9] combined $18 \mathrm{~S}$ rDNA and rbcL to analyse the phylogeny of Chloromonas and Chlamydomonas (Chlorophyceae, Volvocales), with an emphasis on snow and other cold-temperature habitats. Reference [10] demonstrated that Phytophthora de Bary and Peronosporales were a common natural group in phylogenetic studies based on nuclear large subunit ribosomal DNA sequences.
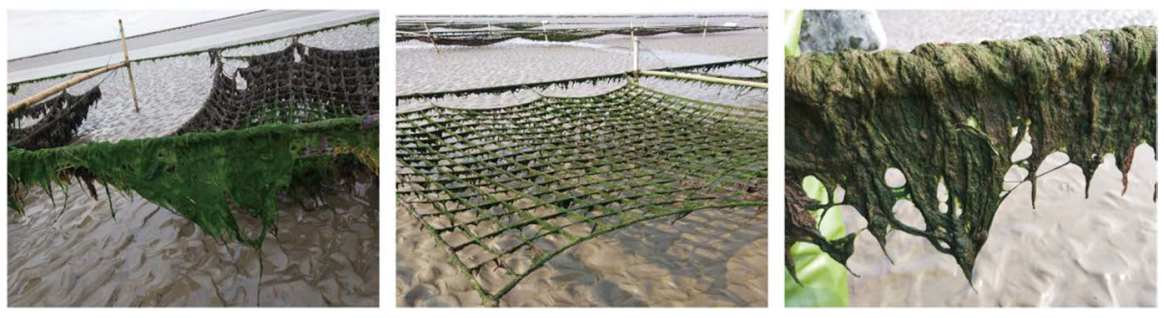

Figure 1. A large amount of Blidingia minima is fixed on a Pyropia farming raft. 
Reference [11] combined ITS data, including the 5.8S rDNA sequence, with morphological data and found that the bloom-forming algae in the Yellow Sea in 2009 and 2010 were the same species. Reference [12] used the intergenic spacer (IGS) region to analyse the genetic variability of Pyropia haitanensis in different areas. Similarity analysis and multisequencing alignment of the sequences indicated that the IGS sequences of different regions of $P$. haitanensis had notable variability. Thus, the sequences of ribosomal transcription units are of great significance in phylogenetic research on marine algae.

This article provides additional information on the classification and identification of green algae. In addition, the methods outlined in this article can be used to obtain the entire ribosomal RNA gene (rDNA) sequence in other green algae taxa.

\section{Materials and Methods}

\subsection{Sample Collection}

Samples of Blidingia minima were collected from ten different sites in the Yellow Sea of China (Table 1). Once the samples were obtained at each site, they were immediately washed with seawater and dried in the shade to a moisture content of $30 \%-40 \%$. Finally, they were transported to the laboratory in an insulated specimen box at $4^{\circ} \mathrm{C}$. All samples used in this experiment were stored in the $\mathrm{Al}$ gae Laboratory of the School of Basic Medical and Biological Sciences, Soochow University, and when fresh algae were obtained, the primary axis, diverged branches, colours and basal part (holdfasts) were recorded and photographed. The samples were sectioned into thin slices with a knife for observation under a microscope. Then, the cell shapes, sizes and arrangements were observed horizontally and vertically; the cell interior structures, such as chromatophores and pyrenoids, were also measured. A microscope (Nikon N90i) and a stereomicroscope (NiKon SMZ 1500) with an image collection system were applied in this research to obtain the main characteristics of the samples (Figure 2).

Table 1. Details of the specimens used in this study.

\begin{tabular}{cccc}
\hline Sample ID & Collection site & Collection date & Latitude and longitude \\
\hline A & Rudong, Nantong & 18 Apr 2018 & $121^{\circ} 20^{\prime} \mathrm{E}, 32^{\circ} 48^{\prime} \mathrm{N}$ \\
B & Rudong, Nantong & $21 \mathrm{Apr} 2017$ & $121^{\circ} 18^{\prime} \mathrm{E}, 32^{\circ} 55^{\prime} \mathrm{N}$ \\
$\mathrm{C}$ & Rudong, Nantong & $20 \mathrm{Apr} 2018$ & $121^{\circ} 21^{\prime} \mathrm{E}, 33^{\circ} 24^{\prime} \mathrm{N}$ \\
$\mathrm{D}$ & Rudong, Nantong & $15 \mathrm{Apr} 2017$ & $121^{\circ} 08^{\prime} \mathrm{E}, 32^{\circ} 37^{\prime} \mathrm{N}$ \\
$\mathrm{E}$ & Rudong, Nantong & $16 \mathrm{Apr} 2017$ & $121^{\circ} 25^{\prime} \mathrm{E}, 32^{\circ} 26^{\prime} \mathrm{N}$ \\
JG1 & Jianggang, yancheng & $24 \mathrm{July} 2018$ & $121^{\circ} 03^{\prime} \mathrm{E}, 32^{\circ} 73^{\prime} \mathrm{N}$ \\
QG & Qionggang, yancheng & $17 \mathrm{Apr} 2017$ & $121^{\circ} 01^{\prime} \mathrm{E}, 32^{\circ} 71^{\prime} \mathrm{N}$ \\
LYG & Lianyungang & $25 \mathrm{Nov} 2018$ & $119^{\circ} 30^{\prime} \mathrm{E}, 34^{\circ} 87^{\prime} \mathrm{N}$ \\
ZQ1 & zhaiqiancun, Haiyang & $24 \mathrm{May} 2018$ & $121^{\circ} 13^{\prime} \mathrm{E}, 36^{\circ} 41^{\prime} \mathrm{N}$ \\
ZQ2 & zhaiqiancun, Haiyang & $24 \mathrm{May} 2018$ & $121^{\circ} 21^{\prime} \mathrm{E}, 36^{\circ} 36^{\prime} \mathrm{N}$ \\
\hline
\end{tabular}




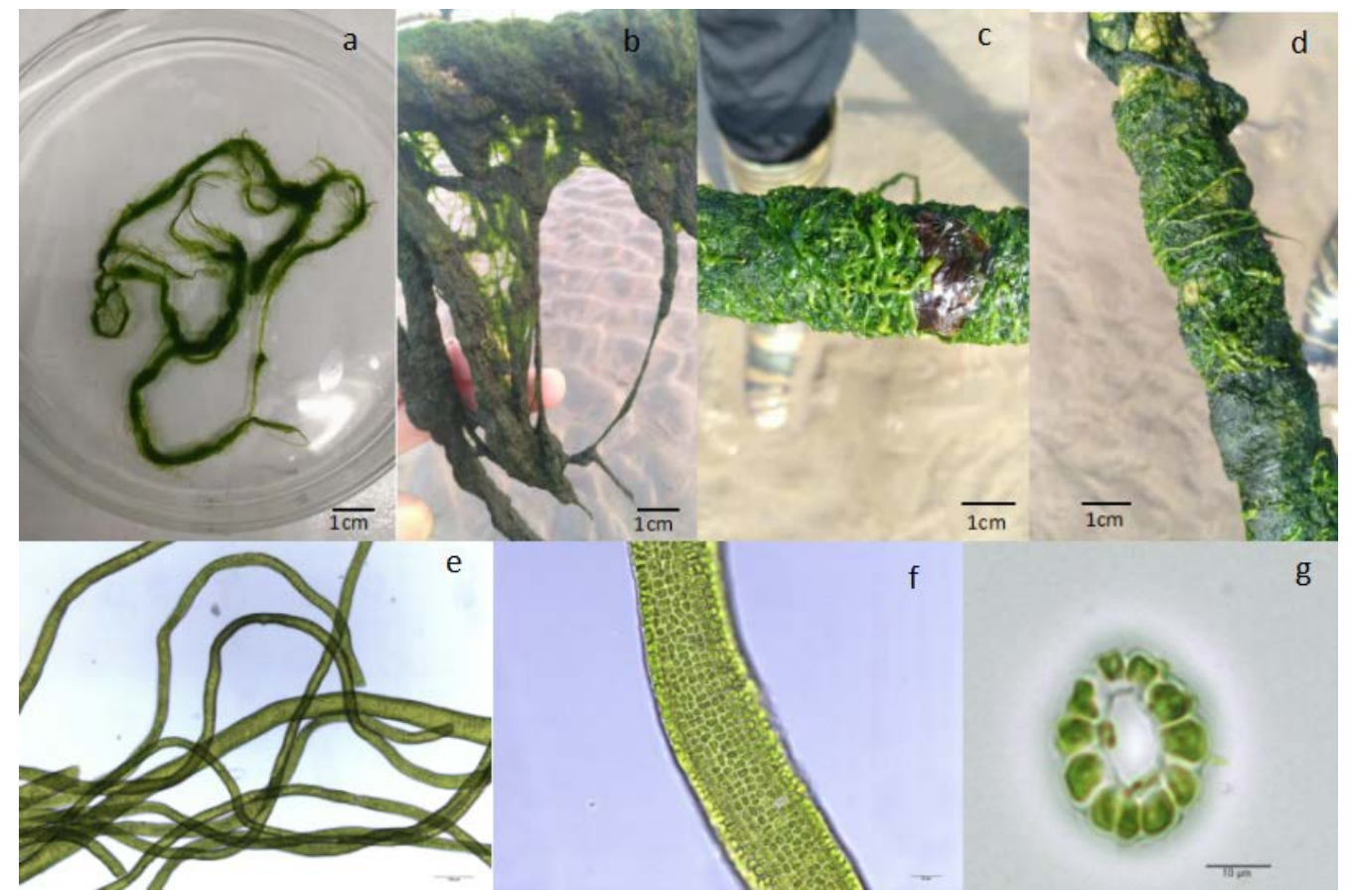

Figure 2. Morphological characteristicsof Blidingia minima. Thallus light-green, simple or branching, Lithophyte. Littoral, in exposed and sheltered localities (a)-(d). Microscopic details of Blidingia minima. The cells located on the lateral side of the body wall and are square or vertical, 5 - $10 \mu \mathrm{m}$ long and 7 - $10 \mu \mathrm{m}$ wide. 1 starch core and chloroplast (e)-(g).

\subsection{Total RNA Extraction}

Fresh algae samples were ground to a powder using an RNase-free mortar and pestle with liquid nitrogen, followed by the addition of $1 \mathrm{ml}$ of Total RNA Extractor (Sangon Biotech, Shanghai) to completely cover the powder, according to the manufacturer's instructions. The concentration and quality of the extracted RNA were preliminarily tested by electrophoresis on $1 \%$ agarose gels. RNA samples were stored at $-80^{\circ} \mathrm{C}$ until use.

\subsection{DNA Extraction}

The algae were removed from the low-temperature refrigerator and placed in sterile double-distilled water for several hours. The algal surface was constantly brushed to remove the debris on the surface of the leaf thallus. The algae were then soaked in $0.7 \% \mathrm{KI}$ for $10 \mathrm{~min}$ and rinsed several times with sterile seawater. Total genomic DNA was extracted by using a Plant Genomic DNA Kit (TIANGEN, BIOTECH (BEIJING) CO., Ltd) according to the instruction manual.

\subsection{3' RACE cDNA Preparation}

First, a poly(A) tail was added to the 3' end of the RNA using poly(A) polymerase (Takara Biotechnology (Dalian) Co., Ltd). Then, $11 \mu \mathrm{L}$ of RNA was combined with $1 \mu \mathrm{L}$ of $3^{\prime}$-CDS primer A, heated to $72^{\circ} \mathrm{C}$ for $3 \mathrm{~min}$ and cooled to $42^{\circ} \mathrm{C}$ for $2 \mathrm{~min}$. Next, $4.0 \mu \mathrm{L}$ of $5 \times$ First-Strand Buffer, $0.5 \mu \mathrm{L}$ of $100 \mathrm{mM}$ DTT, $1.0 \mu \mathrm{L}$ of $20 \mathrm{mM}$ dNTPs, $0.5 \mu \mathrm{L}$ of $40 \mathrm{U} / \mu \mathrm{L}$ RNase inhibitor and $2.0 \mu \mathrm{L}$ of 
SMARTScribe Reverse Transcriptase were added to each reaction tube according to the instructions of the SMART RACE Kit (Clontech). The $20 \mu \mathrm{L}$ reaction was incubated at $42^{\circ} \mathrm{C}$ for $90 \mathrm{~min}$ and then cooled to $70^{\circ} \mathrm{C}$ for $10 \mathrm{~min}$. The cDNA products were diluted with $90 \mu \mathrm{L}$ of EDTA buffer.

\subsection{PCR Amplification and Sequencing}

An overview of the sequence cloning method of the ribosomal RNA gene in Blidingia minima is presented in Figure 3. The primers (Table 2) used in this study were designed with Primer 5.0 software. PCR amplification was carried out in a $50 \mu \mathrm{L}$ volume containing $32.7 \mu \mathrm{L}$ of $\mathrm{ddH}_{2} \mathrm{O}, 5 \mu \mathrm{L}$ of dNTP Mix $(2.5 \mathrm{mM}), 5 \mu \mathrm{L}$ of the template DNA, $5 \mu \mathrm{L}$ of $10 \times$ LA Taq Buffer $\left(\mathrm{Mg}^{2+}\right), 1 \mu \mathrm{L}$ of each primer $(20$ $\mathrm{nmol} / \mathrm{L}$ ), and $0.3 \mu \mathrm{L}$ of LA Taq DNA polymerase (Takara Biotechnology (Dalian) Co., Ltd.). The 3' RACE amplification was performed in a $50 \mu \mathrm{L}$ volume containing $15.5 \mu \mathrm{L}$ of PCR-Grade $\mathrm{H}_{2} \mathrm{O}, 25.0 \mu \mathrm{L}$ of $2 \times$ SeqAmp Buffer, $1.0 \mu \mathrm{L}$ of SeqAmp DNA Polymerase (Clontech), $2.5 \mu \mathrm{L}$ of cDNA, $5 \mu \mathrm{L}$ of $10 \times \mathrm{UPM}$, and 1 $\mu \mathrm{L}$ of $10 \mu \mathrm{M}$ Gsp. Colony PCR was performed in a final volume of $20 \mu \mathrm{L}$ containing $13.8 \mu \mathrm{L}$ of $\mathrm{ddH}_{2} \mathrm{O}, 2 \mu \mathrm{L}$ of dNTP Mix $(2.5 \mathrm{mM}), 2 \mu \mathrm{L}$ of $10 \times$ Ex Taq Buffer $\left(\mathrm{Mg}^{2+}\right), 1 \mu \mathrm{L}$ of $\mathrm{LB}$ medium containing a positive colony, $0.5 \mu \mathrm{L}$ of each primer $(20 \mathrm{nmol} / \mathrm{L})$, and $0.2 \mu \mathrm{L}$ of Ex Taq DNA polymerase (Takara Biotechnology (Dalian) Co., Ltd.).

The PCR amplification cycle is presented in Table 3. The colony PCR conditions were as follows: 3 min initial denaturation at $95^{\circ} \mathrm{C}$; 30 cycles of denaturation at

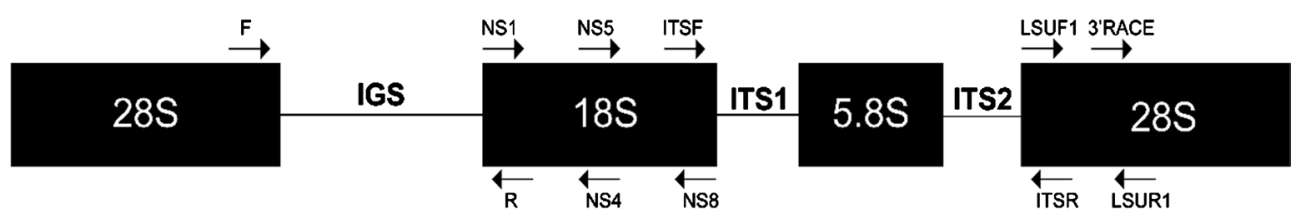

Figure 3. An overview of the sequence cloning method of the ribosomal RNA gene in Blidingia minima.

Table 2. Primers used for amplification in the present study.

\begin{tabular}{|c|c|c|c|c|}
\hline $\begin{array}{l}\text { Primer } \\
\text { name }\end{array}$ & $\begin{array}{c}\text { Gene } \\
\text { product }\end{array}$ & Sequence $\left(5^{\prime} \rightarrow 3^{\prime}\right)$ & $\begin{array}{l}\text { Region and } \\
\text { position }\end{array}$ & Source \\
\hline NS1 & $18 \mathrm{~S}$ rDNA & GTAGTCATATGCTTGTCTC & $5^{\prime}$ end $(\mathrm{F})$ & [13] \\
\hline NS4 & $18 \mathrm{~S} \mathrm{rDNA}$ & CTTCCGTCAATTCCTTTAAG & $-1150(\mathrm{R})$ & [13] \\
\hline NS5 & $18 \mathrm{~S} \mathrm{rDNA}$ & AACTTAAAGGAATTGACGGAAG & $-1150(\mathrm{~F})$ & [13] \\
\hline NS8 & $18 \mathrm{~S}$ rDNA & TCCGCAGGTTCACCTACGGA & 3 ' end (R) & [13] \\
\hline ITSF & ITS + 5.8S rDNA & GAGGCAATAACAGGTCTGTGTGATGC & 5 ' end $(F)$ & In this study \\
\hline ITSR & ITS + 5.8S rDNA & GCTTATTGATATGCTTAAGTTCAGCG & 3' end $(R)$ & In this study \\
\hline LSUF1 & $28 \mathrm{~S}$ rDNA & GTTGAGGCTACCCGCTGAACTTA & 5 ' end $(F)$ & In this study \\
\hline LSUR1 & $28 \mathrm{~S}$ rDNA & CAGAAGATCATGGTCGGTCGATG & 3' end (R) & In this study \\
\hline GSP7 & $28 \mathrm{~S}$ rDNA & CGCAAGGAAACTGACTGGTGGGA & 5 ' end (F) & In this study \\
\hline $\mathrm{F}$ & IGS & AGATAGGACGGGGTATTGTAAG & 5 ' end (F) & In this study \\
\hline $\mathrm{R}$ & IGS & GGATGTGGTAGCCGTTTCTCAG & 3' end $(R)$ & In this study \\
\hline
\end{tabular}


Table 3. PCR reaction profiles for amplifying regions of the ribosomal unit.

\begin{tabular}{|c|c|c|c|c|}
\hline LSUF1/R1 & GSP7(3' RACE) & ITSF/ITSR & $F / R$ & IGSF1/R1 \\
\hline (1) $95^{\circ} \mathrm{C} 3 \mathrm{~min}$ & (1) $94^{\circ} \mathrm{C} 30 \mathrm{~s}$ & (1) $94^{\circ} \mathrm{C} 3 \mathrm{~min}$ & (1) $95^{\circ} \mathrm{C} 3 \mathrm{~min}$ & (1) $95^{\circ} \mathrm{C} 3 \mathrm{~min}$ \\
\hline (2) $94^{\circ} \mathrm{C} 30 \mathrm{~s}$ & (2) $68^{\circ} \mathrm{C} 30 \mathrm{~s}$ & (2) $94^{\circ} \mathrm{C} 30 \mathrm{~s}$ & (2) $94^{\circ} \mathrm{C} 30 \mathrm{~s}$ & (2) $94^{\circ} \mathrm{C} 30 \mathrm{~s}$ \\
\hline (3) $48^{\circ} \mathrm{C} 30 \mathrm{~s}$ & (3) $72^{\circ} \mathrm{C} 5 \mathrm{~min}$ & (3) $53^{\circ} \mathrm{C} 30 \mathrm{~s}$ & (3) $55^{\circ} \mathrm{C} 30 \mathrm{~s}$ & (3) $56^{\circ} \mathrm{C} 30 \mathrm{~s}$ \\
\hline (4) $72^{\circ} \mathrm{C} 1 \mathrm{~min}$ & (4) (1)-(3) 20 cycles & (4) $72^{\circ} \mathrm{C} 1.5 \mathrm{~min}$ & (4) $72^{\circ} \mathrm{C} 5 \mathrm{~min}$ & (4) $72^{\circ} \mathrm{C} 1.5 \mathrm{~min}$ \\
\hline (5) (2)-(4) 35 cycles & & (5) (2)-(4) 35 cycles & (5) (2)-(4) 35 cycles & (5) (2)-(4) 35 cycles \\
\hline (6) $72^{\circ} \mathrm{C} 7 \mathrm{~min}$ & & (6) $72^{\circ} \mathrm{C} 10 \mathrm{~min}$ & (6) $72^{\circ} \mathrm{C} 7 \mathrm{~min}$ & (6) $72^{\circ} \mathrm{C} 7 \mathrm{~min}$ \\
\hline
\end{tabular}

$95^{\circ} \mathrm{C}$ for $30 \mathrm{~s}$, primer annealing at $55^{\circ} \mathrm{C}$ for $30 \mathrm{~s}$, and extension at $72^{\circ} \mathrm{C}$ for $1-5$ $\mathrm{min}$; and a final extension step at $72^{\circ} \mathrm{C}$ for $5 \mathrm{~min}$. One percent agarose gel electrophoresis was used to analyse the PCR products.

The PCR products were purified using the TaKaRa Agarose Gel DNA Purification Kit Ver.4.0 (Takara Biotechnology (Dalian) Co., Ltd.), TA-cloned into the pEASY-T3 vector, and transformed into Trans1-T1 Phage Resistant Chemically Competent Cells (Beijing TransGen Biotech Co., Ltd.). Transformed cells were spread onto LB agar plates containing X-gal, Amp and IPTG, and the plates were then cultivated at $37^{\circ} \mathrm{C}$ for at least $12 \mathrm{~h}$. Positive colonies were picked and cultivated, and the transformed colonies were confirmed by colony PCR. Three positive recombinant colonies of each amplification product were sequenced using Sanger dideoxy sequencing by GENEWIZ Biotechnology Co. Ltd., Suzhou, China.

\section{Sequence Alignment and Analysis}

Nucleotide BLAST was used for sequence alignment with the database to confirm the amplification results. Tandem repeats within the IGS sequence were identified using the Tandem Repeat Finder [14]. Multiple sequence alignment analysis was carried out using the DNAMAN software. Phylogenetic analysis was conducted using MEGA version 5 software [15]. Sequences were aligned using the CLUSTALW program. Bootstrap values obtained after 1000 replications are shown on the branches. The numbers around the branches indicate bootstrap supports.

\section{Results and Analyses}

\subsection{Amplification of the $18 S$ rDNA, ITS + 5.8S rDNA, $28 S$ rDNA and IGS Sequences}

Total genomic DNA or cDNA was used to amplify the fragments of ribosomal RNA in Blidingia minima with the corresponding primers. The $18 \mathrm{~S}$ rDNA was amplified with two pairs of primers (Figure 4(a)), and sequencing and splicing results indicated that the $18 \mathrm{~S}$ rDNA sequence of Blidingia minima was $1759 \mathrm{bp}$ in length. A single target band was successfully amplified with a pair of primers (Figure 4(b)), and the ITS sequence including $5.8 \mathrm{~S}$ was $576 \mathrm{bp}$ in length. Since it 
was difficult to amplify the full-length $28 \mathrm{~S}$ rDNA with only one pair of primers, 3' RACE technology combined with common PCR was applied to amplify this region. The amplified results were finally obtained and are shown in Figure 4(c) and Figure 4(d). After careful analysis, the complete length of the 28S rDNA sequence was determined to be $3282 \mathrm{bp}$. The primers for amplifying IGS sequences were designed based on the $18 \mathrm{~S}$ rDNA and $28 \mathrm{~S}$ rDNA sequences, and the amplified results are shown in Figure 4(e). Finally, through analysis and integration, we obtained the full-length 3059 bp IGS sequences. Each sequence region of the ribosomal RNA was submitted to GenBank with the accession numbers KY235302 (18S rDNA), KY235301 (ITS + 5.8S rDNA), KY401415 (28S rDNA), and KY235300 (IGS). The full-length sequence of the ribosomal RNA gene in Blidingia minima is $8676 \mathrm{bp}$.

\subsection{Base Composition of the $18 \mathrm{~S}$ rDNA, ITS + 5.8S rDNA, $28 \mathrm{~S}$ rDNA and IGS Sequences}

The base composition and GC content of each rDNA fragment were analysed, and the results showed that the C-base contents of the ITS and IGS sequences were the highest, and the G-base contents of the 18S rDNA and $28 \mathrm{~S}$ rDNA sequences were the highest. The GC contents of the $18 \mathrm{~S}$ rDNA, ITS + 5.8S rDNA, $28 \mathrm{SDNA}$ and IGS sequences were $49.57 \%, 62.84 \%, 51.55 \%$ and $53.08 \%$, respectively (Table 4).
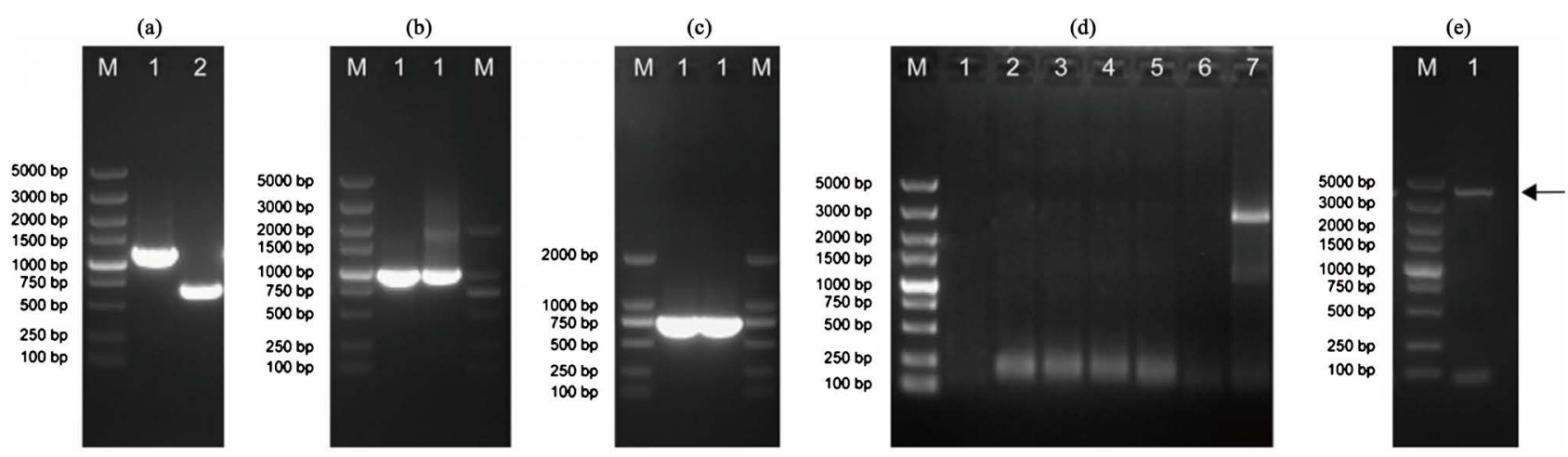

Figure 4. Gel electropherogram of PCR amplification products. (a) Lanes 1 and 2 represent the 18S rDNA sequence of Blidingia minima. (b) Lane 1 represents the ITS sequence of Blidingia minima. (c) Lane 1 represents the first portion of the 28S rDNA sequence in Blidingia minima. M: Takara DL2000 DNA marker (d) Lane 7 represents the second portion of the 28S rDNA sequence of Blidingia minima amplified by 3' RACE. (e) Lane 1 represents the IGS sequence of Blidingia minima. M: Takara DL5000 DNA marker.

Table 4. Base composition of each fragment of rDNA.

\begin{tabular}{|c|c|c|c|c|c|}
\hline \multirow{2}{*}{$\begin{array}{l}\text { Fragments } \\
\quad \text { (bp) }\end{array}$} & \multicolumn{4}{|c|}{ The type of base } & \multirow{2}{*}{ GC (\%) } \\
\hline & A & G & $\mathrm{C}$ & $\mathrm{T}$ & \\
\hline ITS + 5.8S & 104 & 171 & 191 & 109 & 62.84 \\
\hline $18 \mathrm{~S}$ & 441 & 488 & 384 & 446 & 49.57 \\
\hline $28 \mathrm{~S}$ & 850 & 959 & 733 & 740 & 51.55 \\
\hline IGS & 610 & 776 & 848 & 825 & 53.08 \\
\hline
\end{tabular}




\subsection{Phylogenetic Tree Analysis}

Maximum likelihood phylogenetic trees were established based on the ITS sequences (Figure 5). Comparative analysis of the ITS sequences revealed that our amplified species were classified as Blidingia minima and distinguished from other green algae.

Maximum likelihood phylogenetic trees were established based on the IGS sequences (Figure 6) showed that the strains were divided into two big clades. The ZQ1 and ZQ2 strains formed one clade, other eight strains formed another big clade. This result shows that IGS is suitable for intraspecies relationship analysis.

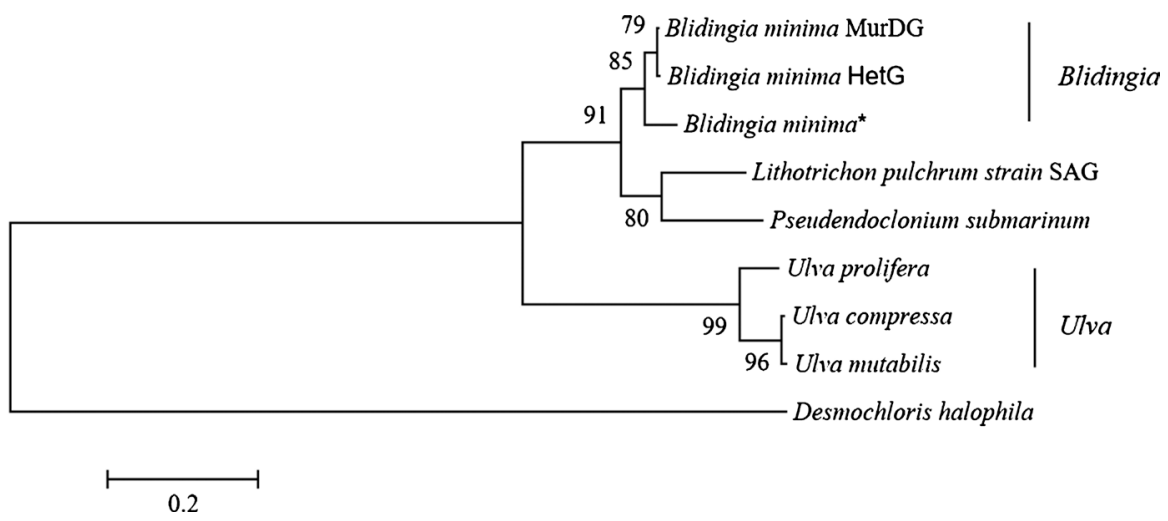

Figure 5. Maximum likelihood trees based on the ITS sequences of various green alage. Asterisks indicate samples from this study. The accession numbers of the sequences (not shown in figure) are Blidingia minima HetG (AF163102); Blidingia minima MurDG (AF163104); Ulva mutabilis (AEU256377); Lithotrichon pulchrum strain SAG (MF034614); Pseudendoclonium submarinum (MF034619); Ulva prolifera (AB830492); Ulva compressa (AB830495); Desmochloris halophila (HE610118).

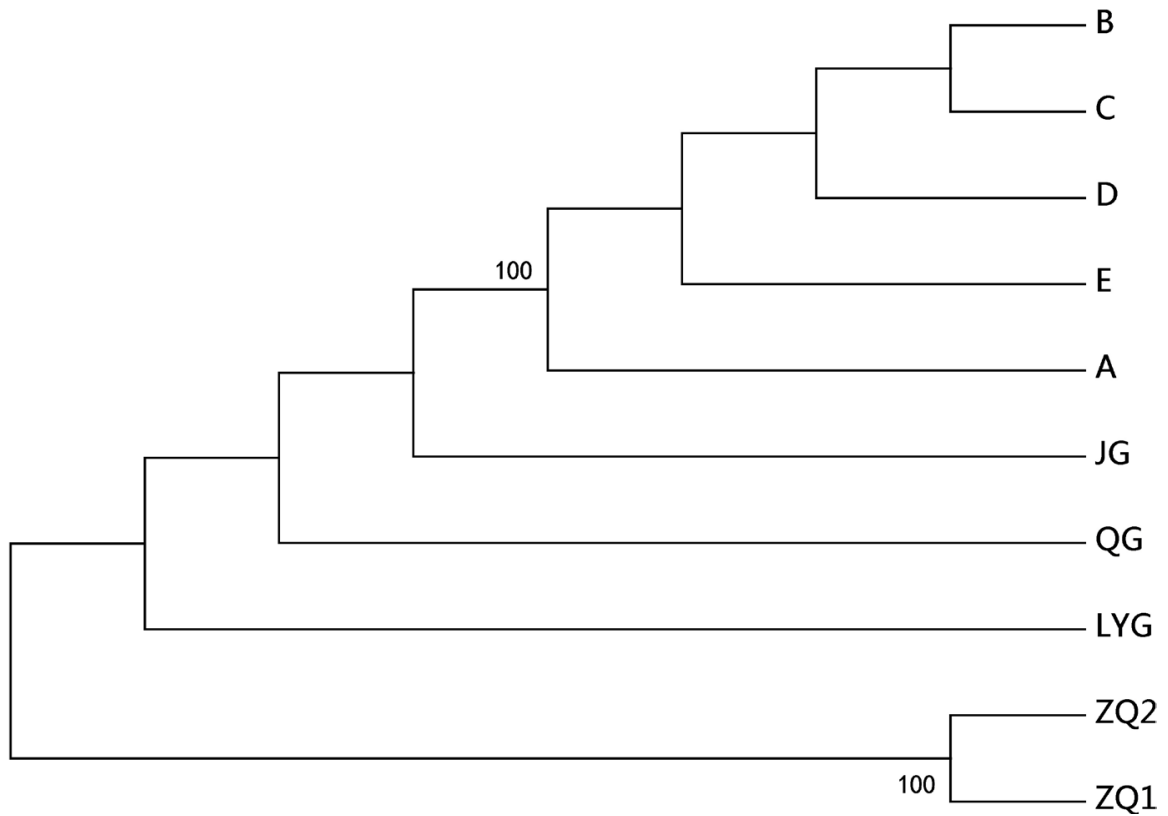

Figure 6. Maximum likelihood trees based on the IGS sequences of ten strains of Blidingia minima, abbreviations of strain names as in Table 1. 


\subsection{Analysis of Special Structures in the IGS}

Two tandem repeats of different lengths at the 5' end of the IGS sequence were found by the Tandem Repeat Finder. In addition, short dyad and palindromic sequences were found in the 3' end and in the middle of the IGS sequence. The locations of specific structures in the IGS sequence are shown in Figure 7, and the detailed characteristics of these special structures are presented in Table 5.

\subsection{IGS Sequence Similarity Analysis}

The lengths of the IGS sequences of 10 strains were all about the same (Figure 8), and the sequences were relatively conserved. Multiple alignment of the IGS sequences of Blidingia minima from 10 different strains (Figure 9) showed multiple base differences, which indicated that the IGS sequences of the strains in different provinces were different, while the strains of the same province had only a few base differences.

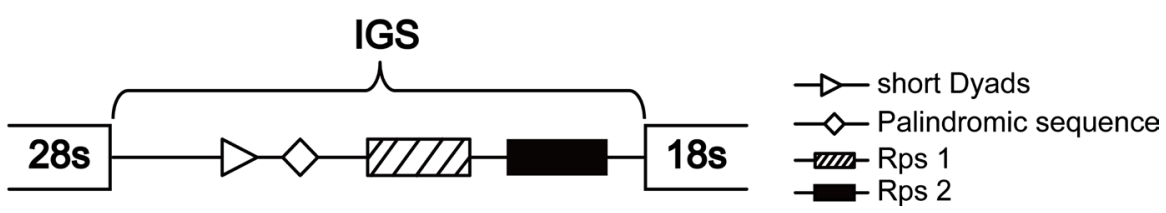

Figure 7. The structures of the IGS region in Blidingia minima.

Table 5. Characterization of special structures presented in the IGS sequence of Blidingia minima.

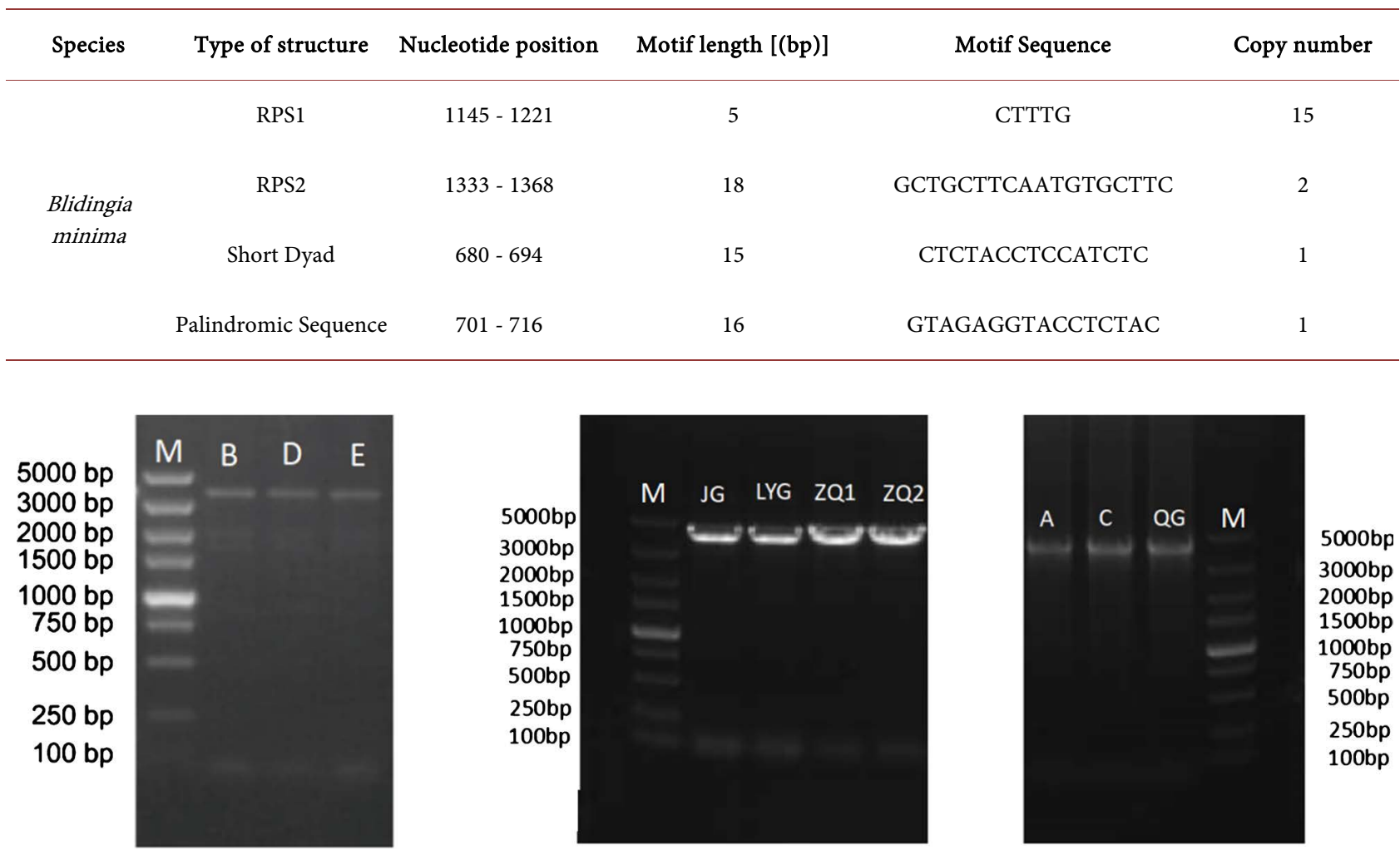

Figure 8. Gel electropherograms of PCR amplification products of Blidingia minima from the A, B, C, D, E, JG, LYG, ZQ1, ZQ2 and QG sites. M: Takara DL5000 DNA marker. 

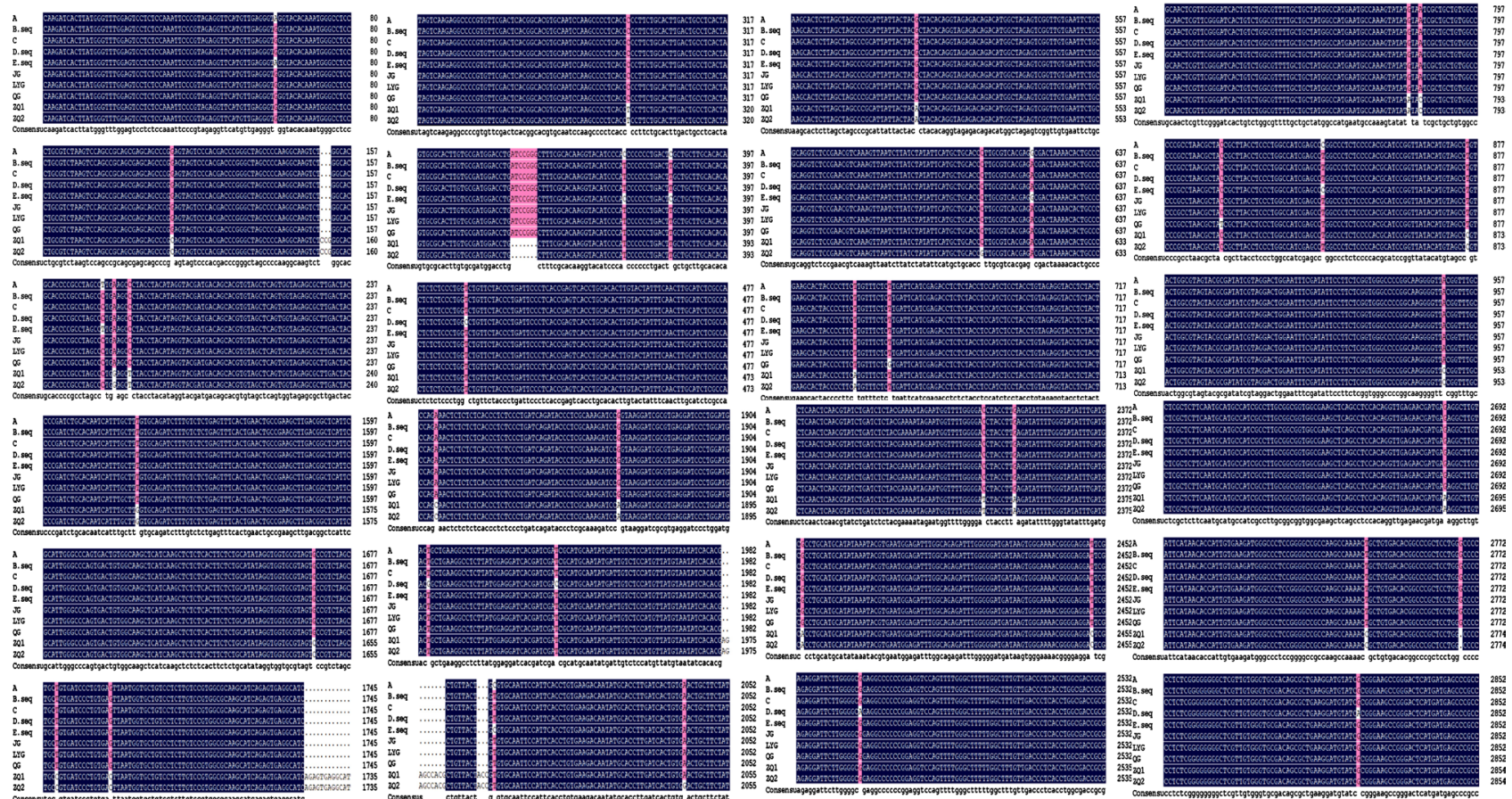

Figure 9. Four parts of alignment of IGS sequences from five strains of Blidingia minima which have obvious differences. Black indicates where base pairs of nucleotides of the five strains were all the same; red indicates where base pairs of nucleotides of one or two strains were different from the other strains; white indicates where base pairs of nucleotides of three or more strains were different from the other strains. Abbreviations of strain names as in Table 1.

\section{Discussion}

In eukaryotic organisms, the $18 \mathrm{~S}$ rDNA, $5.8 \mathrm{~S}$ rDNA, and $28 \mathrm{~S}$ rDNA cluster as one transcript and are separated from the ITS and IGS. The nuclear ribosomal DNA is among the most conserved genes in living creatures (Hassouna et al., 1984) [16]. Because different regions of nuclear ribosomal DNA have different functions, their evolutionary rates are different. Here, we carried out a series of genetic analyses based on the ITS and IGS sequences alone.

In this study, we obtained the full-length sequences of the $8676 \mathrm{bp}$ ribosomal RNA gene (rDNA) in Blidingia minima, which included the 1759 bp $18 \mathrm{~S}$ rDNA, $576 \mathrm{bp}$ ITS + 5.8S rDNA, 3282 bp 28S rDNA, and 3059 bp IGS region. Reference [17] and [18] successfully obtained the complete ribosomal RNA genes of Pyropia yezoensis and Bangia (Bangiales, Rhodophyta). The total length of the ribosomal RNA gene of Pyropia yezoensis was approximately 13,650 bp and that of Bangia was 12,560 bp. Comparing their full-length ribosomal RNA genes revealed that the ribosomal RNA gene of Blidingia minima was much shorter than those of Pyropia yezoensis and Bangia, and the sequence length of each region was also very different. In the process of amplifying the ribosomal RNA gene, we could search for only a partial sequence of the 28S 5' end of the nucleic acid sequence in the NCBI library, and it was very difficult to amplify the complete $28 \mathrm{~S}$ sequence and IGS sequence with only one pair of primers. Therefore, we amplified the known partial sequence by PCR and then amplified the $28 \mathrm{~S} 3$ ' end sequence by rapid amplifica- 
tion using cDNA ends technology. Finally, through sequencing and splicing, a $3282 \mathrm{bp} 28 \mathrm{~S}$ sequence was obtained. In the process of IGS sequence amplification, due to the presence of some specific structures in the IGS sequence, more specific primers and stringent reaction conditions were required in the PCR. Fortunately, we finally obtained a pair of efficient primers and identified the best reaction conditions. The GC content of each unit of the ribosomal RNA sequence unit was analysed and found to be highest in the ITS regions and lowest in the 18S rDNA genes. The total GC content of the ribosomal RNA gene was $54.26 \%$, which was in the range of $35 \%-56 \%$ [19].

Given their high evolutionary rate, ITS sequences are expected to be suitable for detecting interspecific variation [20] [21]. We have made a phylogenetic tree of the amplified ITS sequences, and the results show that our amplified species are clustered together with Blidingia minima, whereas other algae are clustered into another branch, indicating that our expanded ITS can be used as an effective molecular marker to distinguish interspecies relations.

IGS sequences have been widely used as molecular markers, especially for intraspecies relationship analysis; for example, it has been used to distinguish Hordeum [22], Miscanthus [23], rice [24] [25] [26], and Pyropia haitanensis [27]. These regions can also contain functional sequences, such as spacers, promoters and enhancers, and transcription initiation and termination sites [28] [29]. Indeed, the IGS structure is attractive to study because of its importance in the transcription regulation of rRNA genes through the regulation of stop and start signals for transcription of the rDNA units that are located within the region [30] [31]. We compared the full sequence of IGS from 10 strains from different provinces. Strains in the same province were significantly different from IGS sequences in different provinces, which is consistent with the conclusion that the IGS is a highly variable region with a rapid evolutionary rate in Blidingia minima. Therefore, it can provide powerful classification and identification support at the species level and below.

\section{Conclusion}

In this paper, we first amplified the complete nuclear ribosomal DNA sequence of Blidingia minima and carried out a series of genetic analyses based on the ITS and IGS sequences. ITS can be effectively used as a molecular marker for interspecies identification. The phylogenetic tree shows that Blidingia minima can be distinguished from other green algae. We also used IGS to compare the homology of 10 different strains in the Yellow Sea. The results also show that IGS can provide important information for studying the intraspecific relationships and genetic diversity of Blidingia minima.

\section{Acknowledgements}

This work was supported by National Key R\&D Program of China under contract No. 2016YFC1402102. 


\section{Conflicts of Interest}

The authors declare no conflicts of interest regarding the publication of this paper.

\section{References}

[1] Valiela, I., Mcclelland, J., Hauxwell, J., Behr, P.J., Hersh, D. and Foreman, K. (1997) Macroalgal Blooms in Shallow Estuaries: Controls and Ecophysiological and Ecosystem Consequences. Limnology and Oceanography, 42, 1105-1118. https://doi.org/10.4319/lo.1997.42.5_part_2.1105

[2] Raffaelli, D.G., Raven, J.A. and Poole, L.J. (1998) Ecological Impact of Green Macroalgal Blooms. Oceanography and Marine Biology, 125, 97-125.

[3] Liu, D., Keesing, J.K., Xing, Q.G. and Shi, P. (2009) World's Largest Macroalgal Bloom Caused by Expansion of Seaweed Aquaculture in China. Marine Pollution Bulletin, 58, 888-895. https://doi.org/10.1016/j.marpolbul.2009.01.013

[4] Liu, D., Keesing, J.K., Dong, Z., Zhen, Y., Di, B., Shi, Y., et al. (2010) Recurrence of the World's Largest Green-Tide in 2009 in Yellow Sea, China: Porphyra yezoensis Aquaculture Rafts Confirmed as Nursery for Macroalgal Blooms. Marine Pollution Bulletin, 60, 1423-1432. https://doi.org/10.1016/j.marpolbul.2010.05.015

[5] Keesing, J. K., Liu, D., Fearns, P. and Garcia, R. (2011) Inter-And Intra-Annual Patterns of Ulva prolifera Green Tides in the Yellow Sea during 2007-2009, Their Origin and Relationship to the Expansion of Coastal Seaweed Aquaculture in China. Marine Pollution Bulletin, 62, 1169-1182. https://doi.org/10.1016/j.marpolbul.2011.03.040

[6] Harper, J.T. and Saunders, G.W. (2001) The Application of Sequences of the Ribosomal Cistron to the Systematics and Classification of the Florideophyte Red Algae (Florideophyceae, Rhodophyta). Cahiers de Biologie Marine, 42, 25-38.

[7] Poczai, P. and Hyvönen, J. (2010) Nuclear Ribosomal Spacer Regions in Plant Phylogenetics: Problems and Prospects. Molecular Biology Reports, 37, 1897-1912. https://doi.org/10.1007/s11033-009-9630-3

[8] Bianciardi, A., Boschi, M., Swanson, E.E., Belloni, M. and Robbins, L.G. (2012) Ribosomal DNA Organization before and after Magnification in Drosophila Melanogaster. Genetics, 191, 703-723. https://doi.org/10.1534/genetics.112.140335

[9] Hoham, R.W., Bonome, T.A., Martin, C.W. and Leebens-Mack, J.H. (2002) A Combined 18s rDNA and $r b c$ L Phylogenetic Analysis of Chloromonas and Chlamydomonas (Chlorophyceae, Volvocales) Emphasizing Snow and Other Cold-Temperature Habitats. Journal of Phycology, 38, 1051-1064.

https://doi.org/10.1046/j.1529-8817.2002.t01-1-01227.x

[10] Riethmüller, A., Weiss, M. and Oberwinkler, F. (1999) Phylogenetic Studies of Saprolegniomycetidae and Related Groups Based on Nuclear Large Subunit Ribosomal DNA Sequences. Canadian Journal of Botany, 77, 1790-1800.

[11] Luo, M. B. and Liu, F. (2012) Sequence Analysis of ITS Regions of Ulva prolifera in Green Tides in Yellow Sea of China in 2009 and 2010. Marine Environmental Science, 31, 653-656.

[12] Li, Y., Shen, S., He, L., Xu, P. and Lu, S. (2010) Sequence Analysis of rDNA Intergenic Spacer (IGS) of Porphyra haitanensis. Journal of Applied Phycology, 22, 187-193. https://doi.org/10.1007/s10811-009-9441-x

[13] White, T.J., Bruns, T., Lee, S. and Taylor, J. (1990) Amplification and Direct Sequencing of Fungal Ribosomal RNA Genes for Phylogenetics. PCR Protocols, 315-322. https://doi.org/10.1016/B978-0-12-372180-8.50042-1 
[14] Benson, G. (1999) Tandem Repeats Finder: A Program to Analyze DNA Sequences. Nucleic Acids Research, 27, 573-580. https://doi.org/10.1093/nar/27.2.573

[15] Tamura, K., Peterson, D., Peterson, N., Stecher, G., Nei, M. and Kumar, S. (2011) MEGA5: Molecular Evolutionary Genetics Analysis Using Maximum Likelihood, Evolutionary Distance, and Maximum Parsimony Methods. Molecular Biology and Evolution, 28, 2731-2739. https://doi.org/10.1093/molbev/msr121

[16] Hassouna, N., Mithot, B. and Bachellerie, J.P. (1984) The Complete Nucleotide Sequence of Mouse 28S rRNA Gene. Implications for the Process of Size Increase of the Large Subunit rRNA in Higher Eukaryotes. Nucleic Acids Research, 12, 3563-3583. https://doi.org/10.1093/nar/12.8.3563

[17] Li, X., Xu, J., He, Y., Shen, S., Zhu, J.and Shen, Z. (2016) The Complete Nuclear Ribosomal DNA (nrDNA) Cistron Sequence of Pyropia yezoensis (Bangiales, Rhodophyta). Journal of Applied Phycology, 28, 663-669. https://doi.org/10.1007/s10811-015-0522-8

[18] Xu, J., Jiang, B., Chai, S., He, Y., Zhu, J., Shen, Z., et al. (2016) Complete Nuclear Ribosomal DNA Sequence Amplification and Molecular Analyses of Bangia (Bangiales, Rhodophyta) from China. Chinese Journal of Oceanology and Limnology, 34, 1044-1053. https://doi.org/10.1007/s00343-016-5033-1

[19] Freshwater, D.W., Dutcher, J. A., Kapraun, D. F. and Sizemore, R. K. (1990) Variation in Nuclear DNA Base Composition (Mol\% G + C) in Three Orders of Marine Green Algae. Hydrobiologia, 204, 167-172. https://doi.org/10.1007/BF00040229

[20] Leskinen, E. and Pamilo, P. (2004) Evolution of the ITS Sequences of Ribosomal Dna in Enteromorpha (Chlorophyceae). Hereditas, 126, 17-23. https://doi.org/10.1111/j.1601-5223.1997.00017.x

[21] Wörheide, G., Nichols, S. A. and Goldberg, J. (2004) Intragenomic Variation of the rDNA internal Transcribed Spacers in Sponges (Phylum Porifera): Implications for Phylogenetic Studies. Molecular Phylogenetics and Evolution, 33, 816-830. https://doi.org/10.1016/j.ympev.2004.07.005

[22] Georgiev, O., Mishev, K., Krasnikova, M., Kitanova, M., Dimitrova, A. and Karagyozov, L. (2019) The Hordeum Bulbosum 25S-18S rDNA Region: Comparison with Hordeum vulgare and Other Triticeae. Zeitschrift für Naturforschung C, 74, 319-328. https://doi.org/10.1515/znc-2018-0109

[23] Chou, C.H., Chiang, Y. C. and Chiang, T.-Y. (1999) Within- and Between-Individual Length Heterogeneity of the rDNA-IGS in Miscanthus sinensis var. glaber (Poaceae): Phylogenetic Analyses. Genome, 42, 1088-1093. https://doi.org/10.1139/g99-057

[24] Pramateftaki, P.V., Antoniou, P.P. and Typas, M.A. (2000) The Complete DNA Sequence of the Nuclear Ribosomal RNA Gene Complex of Verticillium dahliae: Intraspecific Heterogeneity within the Intergenic Spacer Region. Fungal Genetics and Biology, 29, 19-27. https://doi.org/10.1006/fgbi.1999.1178

[25] Deng, X.Y., Chen, X.Y., Wang, Z.X., Ou, P. and He, J.G. (2006) Cloning, Sequencing and Analysis of the 16S-23S rDNA Intergenic Spacers (IGSs) of Two Strains of Vibrio vulnificus. Acta Genetica Sinica, 33, 365-372. https://doi.org/10.1016/S0379-4172(06)60062-0

[26] Dai, X.J., Ou, L.J., Li, W.J., Liang, M.Z. and Chen, L.B. (2008) Analysis of rDNA Intergenic Spacer (IGS) Sequences in Oryza Sativa L. and Their Phylogenetic Implications. Acta Agronomica Sinica, 34, 1569-1573. https://doi.org/10.3724/SP.J.1006.2008.01569 
[27] He, Y., Shen, S.D. and Shen, Z. (2017) Cloning and Application of the Complete Nuclear Ribosomal DNA (nrDNA) Cistron Sequence of Pyropia haitanensis (Bangiales, Rhodophyta). Botanica Marina, 60, 1515-1526. https://doi.org/10.1515/bot-2016-0079

[28] Dutta, S.K. and Verma, M. (1990) Primary Structure of the Non-Transcribed Spacer Region and Flanking Sequences of the Ribosomal DNA of Neurospora crassa and Comparison with Other Organisms. Biochemical and Biophysical Research Communications, 170, 187-193. https://doi.org/10.1016/0006-291X(90)91258-T

[29] Bhatia, S., Negi, M.S. and Lakshmikumaran, M. (1996) Structural Analysis of the RDNA Intergenic Spacer of Brassica nigra: Evolutionary Divergence of the Spacers of the Three Diploid Brassica Species. Journal of Molecular Evolution, 43, 460-468. https://doi.org/10.1007/BF02337518

[30] Degnan, B.M., Yan, J. and Lavin, M.F. (1998) Evidence of Multiple Transcription Initiation and Termination Sites within the rDNA Intergenic Spacer and Rrna Read through Transcription in the Urochordate Herdmania Curvata. Molecular Marine Biology and Biotechnology, 7, 294-302.

[31] Hemleben, V. and Zentgraf, U. (1994) Structural Organization and Regulation of Transcription by RNA Polymerase I of Plant Nuclear Ribosomal RNA Genes. Results and Problems in Cell Differentiation, 20, 3-24.

https://doi.org/10.1007/978-3-540-48037-2_1 